Abstract

\title{
Women in Violent Extremism in Sweden ${ }^{\dagger}$
}

\author{
Hernan Mondani, Amir Rostami *, Tina Askanius, Jerzy Sarnecki and Christofer Edling
}

Institute for Futures Studies, SE-103 31 Stockholm, Sweden; hernan.mondani@iffs.se (H.M.);

tina.askanius@iffs.se (T.A.); jerzy.sarnecki@iffs.se (J.S.); christofer.edling@iffs.se (C.E.)

* Correspondence: amir.rostami@iffs.se

† Presented at the Global Safety Evaluation Workshop, Online, 1 July-31 December 2020.

Abstract: This presentation summarizes a register-based study on women who have been identified as belonging to three violent extremist milieus in Sweden: violent Islamic, violent far-right, and violent far-left extremism. We studied the women in these milieus along a number of analytical dimensions, ranging from demographic and educational to criminal background and network relationships, and compared them to three reference groups: (i) non-extremist biological sisters to female extremists in the study population; (ii) men in the respective extremist milieus; and (iii) female members of other antagonistic milieus such as organized crime. Our results showed that there are both similarities and differences between groups. In some cases, like age and region of birth, there are commonalities between violent far-right and violent far-left women. Regarding region of birth and migration background, women affiliated to violent far-right and violent far-left extremism are predominantly born in Sweden. Women affiliated to violent Islamic extremism tend to be born in Sweden to a greater extent than men in the same milieu, but to a much lesser degree than women in the violent far-right and violent far-left. When it comes to education, women in the violent Islamic milieu are closer to women in violent far-right extremism. Women in violent far-left extremism perform best at school, with consistently higher grades. The average score of women in violent far-left extremism is identical to that of their sisters, and women in violent far-left extremism perform on average substantially better than men in the same milieu. Women in violent Islamic extremism, in contrast, perform on average similarly to men in violent far-left extremism, and they perform better than their biological sisters. Regarding labor market attachment, violent Islamic extremists have the weakest attachment and the highest dependency upon financial assistance as well as a low employment share (36 percent in 2016), but also a relatively high share of individuals with a high number of unemployment days, suggesting that women in violent Islamic extremism experience higher social exclusion. We find the highest employment share among women in violent far-left extremism, where 89 percent are gainfully employed in 2016 (80 percent for at least three of the last five years) and about a 20 percent unemployment share. Men in violent far-left extremism have an employment share around 10 percent below that of the women in far-left extremism for 2016. The highest fractions of individuals that have not been in contact with the health system due to mental disorders are among violent Islamic extremism, with the women's fraction at 84 percent, compared to their non-extremist sisters and men in the same milieu that are just above 79 percent. Women in violent far-left extremism have the highest share of in-patient major mental disorders among the extremist milieus (3 percent), higher than men in the same milieu (less than 1 percent) as well as than women and their sisters in the other categories. During the period 2007-2016, 68 percent of individuals in the extremist milieus are covered by the register of suspected individuals. The coverage is substantially higher for men, 72 percent than for women, 43 percent. Compared to their sisters, women in all three milieus are criminally active to a much higher extent. However, women in all three milieus are less criminally active than women in other antagonistic milieus, among whom 67 percent have been suspected at least once. In all three milieus, the share of men with a criminal record is about twice as large as that of women. As far as the gender aspect is concerned, we know that extremist milieus generally have a conservative view of the role of women in society. In our results, this is reflected in the low rates of crime in women compared to men, and relatively marginal positions in the co-offending networks. The fact that women in violent far-left extremism have stronger positions in their networks than the other women in the study population is expected,

Copyright: (C) 2021 by the authors. Licensee MDPI, Basel, Switzerland. This article is an open access article distributed under the terms and conditions of the Creative Commons Attribution (CC BY) license (https:// creativecommons.org/licenses/by/ $4.0 /)$. 
given that the ideology of this milieu allows for greater equality. This means that women in violent far-left extremism participate more often than, e.g., women in violent far-right extremism, in political actions where violence is common. This pattern of gender roles and criminal involvement also holds concerning women in violent Islamic extremism. This milieu has a more traditional view of the role of women than views among even violent far-right extremists. Women in violent Islamic extremism are less involved in crime and, in particular, violent crime.

Keywords: violent extremism; crime; female extremists

Institutional Review Board Statement: Ethical review and approval by Regionala etikprövningsnämnden i Stockholm (2017/537-31/5, 2017/1797-32).

Informed Consent Statement: Not applicable.

Data Availability Statement: Data not available due to legal restrictions. 